\title{
Relationship Between Stress Level, Physical Activity, and Consumption Pattern of Magnesium With Emotional Eating in Overweight Adolescents
}

\author{
* $1^{\text {st }}$ Kinanthi Dewi Mutiek \\ Postgraduate Program of Nutrition \\ Science \\ Universitas Sebelas Maret \\ Surakarta, Indonesia \\ Kinanthidm0@gmail.com
}

\author{
$2^{\text {nd }}$ Mohammad Fanani \\ Medical Study Program for Psychiatry \\ Universitas Sebelas Maret \\ Surakarta, Indonesia \\ mohammadfanani@staff.uns.ac.id
}

\author{
$3^{\text {rd }}$ Adi Magna Patriadi Nuhriawangsa \\ Animal Husbandry Study Program \\ Universitas Sebelas Maret \\ Surakarta, Indonesia \\ line 5: email address
}

\begin{abstract}
Emotional eating is one's behavior in excessive consumption of food, which is caused by negative emotions such as stress, anxiety, and depression and which can cause weight gain. Emotional eating can be affected by various factors including stress level, physical activity, and nutrients such as magnesium. This study aims at determining the relationship between stress level, physical activity, and consumption pattern of magnesium with emotional eating in overweight adolescents. This study used observational analytic method cross sectional design. Its population was overweight and obese adolescents aged 15-18 years old in Surakarta. The subjects were 122 adolescents taken by purposive sampling. Emotional eating data were collected through Eating and Appraisal Due to Emotions and Stress (EADES) questionnaire, consumption pattern of magnesium data were gathered by using non-quantitative Food Frequency Questionnaire (FFQ), and physical activity data were obtained through International Physical Activity Questionnaire (IPAQ). Relationship analysis used chi square test with IBM SPSS Statistics 20. The results of show that the stress level had a relationship with the emotional eating in overweight adolescents $(p=0.006)$, the physical activity had a relationship with the emotional eating in overweight adolescents $(p=0.000)$, and the consumption pattern of magnesium had a relationship with the emotional eating in overweight adolescents $(p=0.034)$. Thus, stress level, physical activity, and consumption pattern of magnesium had a relationship with emotional eating in overweight adolescents. Physical activity and consumption pattern of magnesium were the most influential variables on emotional eating in overweight adolescents by $17.8 \%$.
\end{abstract}

Keywords - Emotional eating, Stress level, Physical Activity, Magnesium, Adolescents, Overweight

\section{INTRODUCTION}

Emotional eating is one's behavior in consuming food excessively caused by negative emotions such as stress, anxiety, and depression [1]. Some studies found that emotional eating is caused by several other factors including lifestyle such as quality of sleep, physical activity, and nutrient intake $(8,9,11)$. A study stated that the response of negative emotions causes more excessive consumption of food when feeling sad compared to joy [2]. Excessive consumption of food is carried out as a strategy to relieve stress, but over time this behavior can cause nutritional problems such as overweight and obesity [3]. Other study suggested that overweight and stress have a reciprocal relationship, where being overweight can increase the risk of depression, and vice versa [4]. Increased levels of stress or depression in adolescents are characterized by increased appetite caused by emotions called emotional eating, then emotional eating will lead to weight gain [5]. Adolescents with overweight and obesity will experience an increase in excessive leptin levels so that they will experience lack of leptin sensitivity resulting in disruption of the function to control appetite and energy expenditure [5].

Overweight is caused by various factors including genetics, social and environmental conditions, food consumption, and lack of physical activity. In addition, psychological factors can also affect the prevalence of overweight [6]. Physical activity is one way to prevent overweight, and it also has long-term benefits for human life [7]. A study indicated that physical activity can improve mood, physically active individuals have lower rates of stress and anxiety than inactive ones. In addition, other study also stated that physical activity can reduce emotional eating [8][9].

Serotonin is a hormone synthesized by the central nervous system and cells in the digestive tract and plays an important role in depression, appetite control, and also stress control mechanisms [10]. Serotonin production in the biochemical process requires several nutrients to boost its production (booster) such as amino acid trypthopan. The amino acid Trypthopan is assisted by niacin and magnesium to synthesize serotonin. If the body lacks trypthopan intake, the production of serotonin will decrease, resulting in the appetite control [11]. Magnesium is an important cofactor of various enzymatic reactions in the body and activation of tryptophan hydroxylase to produce serotonin [12]. Low serotonin levels can cause unhealthy eating patterns due to uncontrolled appetite [13]. Therefore, the researcher was interested in conducting this study on relationship between stress level, physical activity, and consumption pattern of magnesium with emotional eating in overweight adolescents. 


\section{MATERIAL AND METHOD}

This study used observational analytic method with cross-sectional design. It was conducted Surakarta City, Central Java Province in February 2020. Its population was all adolescents aged 15-18 years with overweight and obesity. Purposive sampling was used to determine its samples, consisting of 122 respondents. The samples were selected based on inclusion and exclusion criteria. The inclusion criteria of this study were adolescents aged 15-18 years, residing in Surakarta, and BMI/U >1SD. The exclusion criteria in this study were suffering from infectious diseases (such as tuberculosis and diarrhea during the past month), professional athletes, taking water-soluble vitamin supplements, consuming appetite reduction, and severe mental disorders. The respondents signed the informed consent form as evidence of willingness to participate in this study.

Stress level data were collected through Depression Anxiety Stress Scales (DASS 42) questionnaire with the following categories: normal (0-14), mild (15-18), moderate (19-25), severe (26-33) and very severe (> 34) [14]. Physical activity data were gathered through International Physical Activity Questionnaire (IPAQ) with the following categories: vigorous activity (>3000 METs/week), moderate activity (600-3000 METs/week) and light activity $(<600$ METs/week) [15]. Data of consumption pattern of magnesium were obtained by using non-quantitative Food Frequency Questionnaire (FFQ) containing types of highmagnesium foods such as staple foods, beans, side dishes, vegetables and fruits. The consumption pattern was taken during the past month and was scored [24]. The scoring was as follows: if the consumption pattern was $>1 \mathrm{x} /$ day, the score would be 50 , if the consumption pattern was $1 \mathrm{x} /$ day, the score would 25 , if the consumption pattern was $3 \mathrm{x} /$ week, the score would be 15 , if the consumption pattern was 1$2 x /$ week, the score would be 10 , if the consumption pattern was $<1 \mathrm{x} /$ week, the score would be 1 and if the consumption pattern was 0 , the score would be 0 , then the scores were added up and categorized statistically. Emotional eating data were obtained from interview using the Eating and Appraisal Due to Emotions and Stress (EADES) questionnaire and the results were categorized into emotional eating and nonemotional eating [25].

The data were then examined descriptively by looking at the frequency distribution of results of this study. In addition, Chi Square test was performed using the IBM SPSS Statistics 20 to determine the relationship between the independent and dependent variables. This study had ethical approval from the Health Research Ethic Commission of Sebelas Maret

University (031/UN27.06.6.1/KEPK/EC/2020) and permission from the National Unity, Politics, and Community Protection Agency of Surakarta (070/0293/II/2020).

\section{RESULT AND DISCUSSION}

Based on the distribution data of respondents, 70 respondents $(57.4 \%)$ were female and $52(42.6 \%)$ were male. A study stated that emotional eating is more common in females with overweight (20). 87 respondents $(71.3 \%)$ received an allowance of Rp10, 000-20,000 per day, 25 respondents $(20.5 \%)$ received an allowance of $>\mathrm{Rp} 20,000$ per day, and 10 respondents $(8.2 \%)$ received an allowance of $<$ Rp10,000 per day. 75 respondents $(61.5 \%)$ had parental income of > Rp20,000,000, 42 respondents (34.4\%) had parental income of Rp1,000,000-2,000,000, and 5 respondents $(4.1 \%)$ had parental income of < Rp1,000,000. The amount of allowance affects the individual ability to purchase the desired food, the higher allowance amount is, the higher the purchasing power for foods will be to meet one's appetite. This also applies to the parental income [26].

56 respondents $(45.9 \%)$ experienced emotional eating and 66 respondents $(54.1 \%)$ did not experience emotional eating. 25 respondents $(20.5 \%)$ experienced moderate stress level, 21 respondents $(17.2 \%)$ experienced mild stress level, and 76 respondents $(62.8 \%)$ experienced normal stress level. Data on the respondents' physical activity found that 61 respondents $(50 \%)$ performed moderate physical activity, 33 respondents $(27 \%)$ performed light physical activity and 28 respondents $(23 \%)$ performed vigorous physical activity (Table I). A study suggested that stress level and physical activity have an effect on emotional eating in overweight adolescents in relation to balanced serotonin levels [20].

TABLE I. DISTRIBUTION OF GENDER, ALLOWANCE, PARENTAL INCOME, EMOTIONAL EATING, PHYSICAL ACTIVITY, STRESS LEVEL, CONSUMPTION PATTERN OF MAGNESIUM

\begin{tabular}{|c|c|c|c|}
\hline \multirow{2}{*}{ NO } & \multirow{2}{*}{ Variable } & \multicolumn{2}{|c|}{ Amount } \\
\hline & & $n$ & $\%$ \\
\hline \multirow{3}{*}{1} & Gender & & \\
\hline & Male & 52 & 42.6 \\
\hline & Female & 70 & 57.4 \\
\hline \multirow{4}{*}{2} & Allowance/day & & \\
\hline & $>20.000$ & 25 & 20.5 \\
\hline & $10.000-20.000$ & 87 & 71.3 \\
\hline & $<10.000$ & 10 & 8.2 \\
\hline \multirow{4}{*}{3} & Parental income & & \\
\hline & $>2.000 .000$ & 75 & 61.5 \\
\hline & $1.000 .000-2.000 .000$ & 42 & 34.4 \\
\hline & $<1.000 .000$ & 5 & 4.1 \\
\hline \multirow{3}{*}{4} & Emotional eating & & \\
\hline & Emotional eating & 56 & 45.9 \\
\hline & Non-emotional eating & 66 & 54.1 \\
\hline \multirow{4}{*}{5} & Stress Level & & \\
\hline & Normal & 76 & 62.3 \\
\hline & Light & 21 & 17.2 \\
\hline & Moderate & 25 & 20.5 \\
\hline \multirow{4}{*}{6} & Physical activity & & \\
\hline & Light & 33 & 27 \\
\hline & Moderate & 61 & 50 \\
\hline & Vigorous & 28 & 23 \\
\hline \multirow{3}{*}{7} & Consumption Pattern of & & \\
\hline & Rarely & 58 & 47.5 \\
\hline & Often & 64 & 52.5 \\
\hline
\end{tabular}


TABLE II. RELATIONSHIP BETWEEN STRESS LEVEL, PHYSICAL ACTIVITY, AND CONSUMPTION PATTERN OF MAGNESIUM WITH EMOTIONAL EATING IN OVERWEIGHT ADOLESCENTS

\begin{tabular}{|c|c|c|c|c|c|c|}
\hline \multirow[t]{2}{*}{ NO } & \multirow[t]{2}{*}{ Variable } & \multicolumn{2}{|c|}{$\begin{array}{l}\text { Emotional } \\
\text { eating }\end{array}$} & \multicolumn{2}{|c|}{$\begin{array}{c}\text { Non-emotional } \\
\text { eating }\end{array}$} & \multirow[t]{2}{*}{ P value } \\
\hline & & $N$ & $\%$ & $N$ & $\%$ & \\
\hline \multirow{4}{*}{1} & \multicolumn{5}{|l|}{ Stress level } & \multirow[t]{4}{*}{0.006} \\
\hline & Normal & 28 & 36.8 & 48 & 63.2 & \\
\hline & Light & 16 & 76.2 & 5 & 23.8 & \\
\hline & Moderate & 12 & 48 & 13 & 52 & \\
\hline \multirow{4}{*}{2} & \multicolumn{5}{|c|}{ Physical activity } & \multirow[t]{4}{*}{0.000} \\
\hline & Light & 26 & 78.8 & 7 & 21.2 & \\
\hline & Moderate & 21 & 34.4 & 40 & 65.6 & \\
\hline & Vigorous & 9 & 32.1 & 19 & 67.9 & \\
\hline \multirow{3}{*}{3} & \multicolumn{5}{|c|}{$\begin{array}{l}\text { Consumption pattern } \\
\text { of magnesium }\end{array}$} & \multirow[t]{3}{*}{0.034} \\
\hline & Rarely & 32 & 56.1 & 25 & 43.9 & \\
\hline & Often & 24 & 36.9 & 41 & 63.1 & \\
\hline
\end{tabular}

Table II shows that stress level had an effect on the emotional eating in overweight adolescents with the p-value of 0.006 ( $\mathrm{p}<0.05) .36 .8 \%$ of adolescents with normal stress levels experienced emotional eating, and $63.2 \%$ of adolescents with normal stress levels did not experience emotional eating. $76.2 \%$ of adolescents with mild stress levels experienced emotional eating, and $23 \%$ of adolescents with mild stress levels did not experience emotional eating. $48 \%$ of adolescents with moderate stress levels experienced emotional eating, and $52 \%$ of adolescents with moderate stress levels did not experience emotional eating. The finding of this study is consistent with those of previous study in that the higher the stress level is, the more likely to experience emotional eating will be, where individuals with emotional eating consume more foods than those without emotional eating. This is because emotional eating is a coping mechanism to stress experienced by individuals $(16,17.18)$. High levels of stress in overweight adolescents affect the balance of hormones in the body, including leptin. If leptin sensitivity decreases, it will affect the regulation of appetite and energy expenditure (19). Physical activity had a significant effect on emotional eating with the $\mathrm{p}$ value of $0.000(\mathrm{p}<0.05)$.

The results of this study indicate that $78.8 \%$ of adolescents performing mild physical activity experienced emotional eating but $21.2 \%$ did not; $34.4 \%$ of adolescents performing moderate physical activity experienced emotional eating, but $65.6 \%$ did not; and $32.1 \%$ of adolescents performing vigorous physical activity experienced emotional eating, but $67.9 \%$ did not. The finding is consistent with that of previous study that physical activity can reduce stress level, improve mood, and reduce emotional eating. The results of other experimental study indicated that regular physical activity for two months affects regulation of stress behavior and decreased risk of emotional eating over time $(9,21,7)$. Physical activity and sleep quality of an individual also affect the balance of serotonin in the body in regulating stress. Physical activity can increase serotonin production which has an impact on emotional improvement and appetite control (22).

The results of this study indicate that consumption pattern of magnesium had an effect on emotional eating in adolescents with the $p$ value of $0.034(p<0.05) .56 .1 \%$ of the adolescents who rarely consumed magnesium-rich food sources experienced emotional eating but $43.9 \%$ did not. In contrast, $63.1 \%$ of the adolescents who often consumed magnesium-rich food sources did not experience emotional eating but $36.9 \%$ did. Thus, the group rarely consuming magnesium food sources was more at risk of experiencing emotional eating. Previous study revealed that magnesium intake has an effect on serotonin levels in the blood of depressed patients (23). Serotonin is a hormone synthesized by the central nervous system and cells in the digestive tract and plays an important role in depression, appetite control, and also stress control mechanism (10). Serotonin production in the biochemical process requires several nutrients that can boost its production (booster) such as the amino acid trypthopan. The amino acid Trypthopan is assisted by niacin and magnesium to synthesize serotonin, if the body lacks trypthopan intake, the production of serotonin will decrease, resulting in the appetite control $(10,11)$.

The results of multivariate test using multiple linear regression indicate that physical activity $(\mathrm{p}=0,000)$ and consumption pattern of magnesium $(\mathrm{p}=0.030)$ had $\mathrm{a}$ significant effect on the emotional eating in overweight adolescents. It was obtained that the $\mathrm{R}$ square value was 0.178 , meaning that physical activity and consumption pattern of magnesium had an effect on emotional eating in overweight adolescents by $17.8 \%$. The limitation of this study was that the researcher only examined consumption pattern and did not examine magnesium intake and other nutrients affecting emotional eating. In addition, this study did not examine serotonin levels in the blood so that it has not been able to describe the results of study with quantitative data.

\section{CONCLUSION}

The results of this study point out that stress levels have a positive effect on emotional eating in overweight adolescents. The higher the stress levels are, they will further increase emotional eating in overweight adolescents. Physical activity has a negative effect on emotional eating in overweight adolescents. The higher physical activity is, it will further reduce emotional eating in overweight adolescents. The consumption pattern of magnesium has a negative effect on emotional eating in overweight adolescents. The more often magnesium is consumed, it will further reduce emotional eating in overweight adolescents. Physical activity and consumption pattern of magnesium are the most influential variables on emotional eating in overweight adolescents by $17.8 \%$.

\section{ACKNOWLEDGMENT}

We extend our gratitude to our colleagues and family for their support and to those who have helped us in the completion of this article.

\section{REFERENCES}

[1] Van Strien, T., Cebolla, A., Etchemendy, E., Gutierrez-Maldonado J., Ferrer-García, M., Botella, C., "Emotional eating and food intake aftersadness and joy", Appetite, Vol. 66, pp 20-25, 2013.

[2] Nolan, L.J., Halperin, L.B., Geliebter, A, "Emotional Appetite uestionnaire.Construct validity and relationship with BMI", Appetite, Vol. 54 (2), 314-319, 2010.

[3] Luppino, F. S., de Wit, L. M., Bouvy, P. F., Stijnen, T., Cuijpers, P., Penninx, B. W.," Overweight, obesity, and depression a systematic review and metaanalysisof longitudinal studies", Archives of General Psychiatry, Vol. 67(3), 220-229, 2010. 
[4] American Psychiatric Association, "Diagnostic and statistical manual of mental disorders (5th ed.)" Washington, DC: American Psychiatric Pub, 2013.

[5] Jespinder Kaur, "A Comprehensive Review on Metabolic Syndrome", Cardiology Research and Practice, 2014: 943162 , 2014.

[6] Adriaanse, M. A., De Ridder, D. T. D., Evers, C.R, "Emotional eating: Eating when emotional or emotional about eating?", Psychology \& Health, Vol.26, 23-39, 2011.

[7] Dohle, S., Wansink, B Y, "Fit in 50 years: Participation in high school sports best predicts one's physical activity after age 70", BMC Public Health, Vol.13, 1100, 2013.

[8] King, N. A., Caudwell, P., Hopkins, M., Byrne, N. M., Colley, R., Hills, A. P. Blundell, J. E." Metabolic and behavioral compensatory responses to exercise interventions: Barriers to weight loss", . Obesity, Vol. 15, 1373-1383.2007.

[9] Van Strien, T., Koenders P, "How do physical activity, sports, and dietary restraint relate to overweight-associated absenteeism?", Journal of Occupational and Environmental Medicine, Vol.52, 858864,2010

[10] Haider, S., Khaliq, S., Ahmed, S.P., Haleem, D.J., "Long-term tryptophan administration enhances cognitive performance and increases 5HT metabolism in the hippocampus of female rats" Amino Acids, Vol. 31, 421-425. 2006.

[11] Singh K, "Nutrient and Stress Management". Nutr Food Sci, Vol. 6:4, 2016.

[12] Wolf FI, Trapani V, “ Cell (patho) physiology of magnesium”. Clin Sci, Vol. 114: 27-35. 2008.

[13] Hartman J, Marieke W, Alex L, Catherine D, “ The serotonin transporter 5-HTTLPR polymorphism in the association between sleep quality and affect", European Neuropsychopharmacology, Vol.24,1086-1090, 2014.

[14] Crawford, John. R \& Henry, Julie. D. "The Short -Form Version of the Depression Anxiety Stres Scales (DASS-24)": Construct Validity and Normative Data in 1 Large Non-Critical Sample. Australia: The British Psychological Society.2005.
[15] IPAQ."Guidelines For Data Processing and Analysis of The International Physical Activity Questionnaire (IPAQ) Short and Long Forms", 2005.

[16] Young D, Cheistine A.L,"Avoidant coping moderates the relationship between stress nd depressive emotional eating in adolescents", Eat Weight Disord, Vol.22(4), 683-691,2017.

[17] Spoor STP, Bekker MHJ, Van Strien T, Van Heck GL, "Relations between negative affect, coping, and emotional eating", Appetite ,Vol. 48(3):368-376, 2007.

[18] Osborn RL, Sbrocco T, Spieker E, Wood A, "Emotional eating as coping: understanding the role of alexithymia and food type." Ann Behav Med, Vol. 39:21. 2010

[19] Jespinder Kaur, "A Comprehensive Review on Metabolic Syndrome”, Cardiology Research and Practice, 2014: 943162 , 2014.

[20] Van Strien, T., Konttinen, H., Homberg, J. R., Engels, R. M., \& Winkens, L. H. "Emotional eating as a mediator between depression and weigh gain". Appetite, Vol. 100, page 216-224. 2016.

[21] Oaten, M., \& Cheng, K., "Longitudinal gains in self-regulation from regular physical exercise". British Journal of Health Psychology, Vol. $11,717-733,2006$

[22] Klempin F, Beis D, Mosionko V, "Serotonin Is Reqired for exerciseinduced adult hippocampal neurogenesis" The Jurnal of Neuroscience, Vol. 33 (19). 8270-5, 2013.

[23] Ruljancic M., Mate M., Ivana C., et.al, "Platelet serotonin and magnesium concentrations in suicidal and non-suicidal depressed patients", Magnesium Research, Vol.26 (1): 9-17.2013.

[24] Suhardjo, "Perencanaan Pangan dan Gizi" Jakarta: Bumi Aksara.2010.

[25] Ozier A.D, OliviaW., Linda L., James D, Mike P, Joy B, "The Eating and Appraisal Due to Emotions and Stress (EADES) Questionnaire: Development and Validation". J Am Diet Assoc, Vol. 107(4):619-28, 2007.

[26] Desi, S dan Winda DA, "Hubungan Saraan, Uang Saku dengan Jajanan di SD Kristen Immanuel II Kubu Raya” Jurnal Vokasi Kesehatan :106-107. 2018. 